\title{
Phosphatase activities of spruce stand soils after serpentinite fertilisation in combination with nitrogen, phosphorus and potassium fertilisers
}

\author{
Kazimierz Januszek, Ewa Błońska $\bowtie$, Tomasz Wanic, Stanisław Małek \\ University of Agriculture in Krakow, Faculty of Forestry, al. 29 Listopada 46, 31-425 Kraków, Poland, \\ phone: 4812 6625031, e-mail: eblonska@ar.krakow.pl
}

\begin{abstract}
The aim of this study was to assess the condition of soil after serpentine fertilisation by determining the activity of phosphatase and some physicochemical properties of soil. The study was conducted in southern Poland in the Wisła Forest District (49³ $\left.38^{\prime} 12.92 \mathrm{~N} 18^{\circ} 58^{\prime} 56.36 \mathrm{E}\right)$. The following variants: $\mathrm{C}$ - control - no fertiliser; $\mathrm{S}$ - ground serpentinite; SN - serpentinite + nitrogen; SP - ground serpentinite + P; SNP - ground serpentinite + NP; SNPK - ground serpentinite + NP (as above) + K. Fertilisation of serpentinite stimulates the activity of phosphatase in soil under spruce stands. The positive impact is reflected in the organic horizon. Less activity was noted in the humus-mineral horizon (AE) in all the fertiliser combinations three years after the fertilisation. Fertilisation of serpentinite improves the chemical properties $-\mathrm{pH}$ was increased, reduction of molar ratio of exchangeable calcium to magnesium form was noted.
\end{abstract}

\section{KEY WORDS}

serpentinite fertilisation, forest soils, spruce stands

\section{INTRODUCTION}

Availability of phosphorus may be a limiting factor for plant growth in many ecosystems (Attwill and Adams 1993). Most plants demand for phosphorus is satisfied by the transformation of soil organic matter. Disturbance in the economy of phosphorus is one of the causes of weakening growth and the beginning of disease conditions in the stands. The soil phosphatase activities greatly affect the bioavailability of organic P (Wang et al. 2011). The enzyme activities are known to catalyze a web of reactions necessary for life processes of microorganisms, de- composition of organic residues, cycling of nutrients, formation of organic matter and soil structure (Ekenler and Tabatabai 2003). Phosphatase activity in the soil environment reflects the activity of enzymes associated with soil colloids and humic substances, free phosphatases associated with live and dead cells of plants and microorganisms (Nannipieri et al. 1990). Phosphatase may be a good indicator of the potential of organic phosphorus mineralisation and soil biological activity (Bielińska 2005). Mijangos et al. (2006) tested phosphatase activity as a sensitive indicator of the effects of agricultural practices (fertilisation and tillage) on soil properties. 
The aim of this study was to assess the condition of soil after serpentine fertilisation in combination with nitrogen, phosphorus and potassium fertiliser by determining the activity of phosphatase and some physicochemical properties of soil. We hypothesised that (1) heavy metals especially nickel introduced with the fertiliser do not have a negative impact on the phosphatase activity, (2) fertilisation improves the chemical properties and phosphatase activity which can be an indicator of soil biological activity.

\section{Material AND MEthods}

\section{Study area and experimental design}

The study was conducted in southern Poland in the Wisła Forest District (49³8'12.92N, 1858'56.36E). The experimental plots were set up in the areas of the Silesian Nappe in the range of Barania Góra mountain, built of the lower Istebna layers, consisting of thick-bedded sandstones and conglomerates producing sandy-clayey waste-mantle with oligotrophic soils, which are susceptible to degradation.

The experiment was carried out on plots measuring 1 ar while the width insulating strips between plots was 5 meters; a total of 18 plots were established in Wisła Forest District. Samples for laboratory testing were collected from five plots of different nutrition treatment variants in three replications.

Serpentinite was introduced in the autumn of 2008, and other fertilisers in the spring of 2009. The following variants: $\mathrm{C}$ - control - no fertiliser; $\mathrm{S}$ - ground serpentinite $(4000 \mathrm{~kg} / \mathrm{ha}) ; \mathrm{SN}$ - serpentinite + nitrogen $(440 \mathrm{~kg}$ ammonium nitrate $(34 \% \mathrm{~N}) / \mathrm{ha}(150 \mathrm{~kg} \mathrm{~N} / \mathrm{ha}))$; SP - ground serpentinite $+\mathrm{P}(400 \mathrm{~kg}$ of granulated triple superphosphate $(20 \% \mathrm{P}) / \mathrm{ha})$; SNP - ground serpentinite + NP (440 kg ammonium nitrate/ha - $150 \mathrm{~kg} \mathrm{~N} / \mathrm{ha}$ and $400 \mathrm{~kg}$ of granulated triple superphosphate $/ \mathrm{ha}-80 \mathrm{~kg}$ $\mathrm{P} / \mathrm{ha}$ ); SNPK - ground serpentinite + NP (as above) + K ( $250 \mathrm{~kg}$ of potassium sulphate $44 \% \mathrm{~K} / \mathrm{ha}-110 \mathrm{~kg} \mathrm{~K} / \mathrm{ha}$ ). Macro- (\%) and some microelement (mg.kg-1 of soil) in serpentinite used as a fertiliser of investigated plots: $\mathrm{C}-1.67, \mathrm{~N}-0.001, \mathrm{~S}-0.011, \mathrm{Na}-0.009, \mathrm{~K}-0.006$, $\mathrm{Ca}-0.39, \mathrm{Mg}-18.10, \mathrm{Fe}-5.77 ; \mathrm{Mn}-621.5, \mathrm{Zn}-38.4$, $\mathrm{Cu}-11.5, \mathrm{Cd}-1.96, \mathrm{Ni}-1673.21, \mathrm{~Pb}-1.25, \mathrm{Cr}-131.5$.

\section{Soil sampling}

The samples for laboratory testing were collected on the experimental areas in August 2010, 2011 from plots of different nutrition treatment variants. The samples for laboratory testing were collected from the organic horizon (without further subhorizons) and from the mineral horizons down (AE) in three replications. For the determination of enzymatic activity fresh samples of natural moisture were taken. The samples were stored at $4^{\circ} \mathrm{C}$ before the analysis.

\section{Soil properties}

The collected samples were first dried at room temperature to an air-dry condition and then sieved through a $2 \mathrm{~mm}$ sieve. The analysis of sample parameters included:

- soil $\mathrm{pH}$ in $\mathrm{H}_{2} \mathrm{O}$ and $1 \mathrm{M} \mathrm{KCl}$ solution, determined potentiometrically, with soil-to-solvent proportion of 1:2.5 for mineral soils and 1:5 for organic soils;

- exchangeable acidity $\left(\mathrm{H}_{\mathrm{w}}\right)$ and exchangeable aluminium $\left(\mathrm{H}_{\mathrm{Al}}\right)$, determined by the Sokołow method;

- hydrolytic acidity (Y) was marked with Kappen method;

- general nitrogen content and carbon content was marked using the LECO analyzer, with calculating $\mathrm{C} / \mathrm{N}$ ratio;

- alkaline cation content in $1 \mathrm{M}$ ammonium acetate with a calculation of effective cations exchange capacity $T_{e}$ and the degree of soil saturation with alkaline cations ( $\mathrm{V} \%$ );

- available phosphorus with Bray-Kurtz method.

Phosphatase activity was marked with Kramer and Erdei (1959) method, which adopted a $2.5 \mathrm{hr}$ development time for the colorimetric determination of phenol (Tabatabai and Bremner 1969).

\section{Statistical analysis}

Statistical data analysis was performed using the program Statistica 9, differences between the mean values from the two samples were tested with Kruskal-Wallis test. We also calculated Pearson's correlation coefficients between the physico-chemical properties and enzyme activities. 


\section{DE GRUYTER \\ OPEN}

\section{Results}

\section{Soil properties}

In 2010, in the Ofh horizon in all the variants of fertilisation in relation to the control $\mathrm{pH}$ was increased. In the AE horizon compared to the control only in the SP fertilisation variant $\mathrm{pH}$ was increased. In other variants decrease $\mathrm{pH}$ was noted (tab. 1). In 2011 in the Ofh in all variants of fertilisation $\mathrm{pH}$ was increased, a slight increase was observed in the AE horizon (tab. 2). The

Table 1. The average values of the properties of the testes soils in the 2010

\begin{tabular}{|c|c|c|c|c|c|c|c|c|c|c|c|c|}
\hline \multirow[t]{2}{*}{ Plots } & \multirow[t]{2}{*}{ Horizon } & \multirow{2}{*}{$\begin{array}{l}\text { Types of } \\
\text { fertilisa- } \\
\text { tion }\end{array}$} & \multirow{2}{*}{$\mathrm{pH} \mathrm{H} \mathrm{H}_{2} \mathrm{O}$} & \multirow[t]{2}{*}{$\mathrm{pH} \mathrm{KCl}$} & $\mathrm{Y}$ & $\mathrm{Hw}_{\left(\mathrm{Al}^{3+}\right)}$ & $\mathrm{S}$ & $\mathrm{T}_{\mathrm{e}}$ & \multirow[t]{2}{*}{$V_{e}(\%)$} & $\begin{array}{c}\text { Organic } \\
\mathrm{C}\end{array}$ & $\mathrm{N}$ total & \multirow[t]{2}{*}{$\mathrm{C}: \mathrm{N}$} \\
\hline & & & & & \multicolumn{4}{|c|}{$\mathrm{cmol}(+) \cdot \mathrm{kg}^{-1}$} & & \multicolumn{2}{|c|}{$\mathrm{g} \cdot \mathrm{kg}^{-1}$} & \\
\hline \multirow{12}{*}{ Wisła } & \multirow{6}{*}{ Ofh } & $\mathrm{C}$ & 3.60 & 2.83 & 88.59 & 1.40 & 5.08 & 22.16 & 22.83 & 326.7 & 14.0 & 23.23 \\
\hline & & $\mathrm{S}$ & 3.97 & 3.07 & 80.61 & 1.49 & 11.05 & 26.21 & 41.54 & 324.1 & 13.8 & 23.43 \\
\hline & & $\mathrm{SN}$ & 4.08 & 3.13 & 77.72 & 1.28 & 12.23 & 23.69 & 51.93 & 329.6 & 13.2 & 24.83 \\
\hline & & $\mathrm{SP}$ & 3.99 & 3.08 & 78.38 & 1.07 & 10.97 & 24.78 & 43.83 & 325.5 & 13.6 & 23.94 \\
\hline & & SNP & 4.12 & 3.18 & 77.05 & 1.33 & 13.77 & 24.97 & 55.24 & 358.4 & 14.3 & 25.07 \\
\hline & & SNPK & 3.97 & 3.06 & 86.12 & 1.24 & 12.30 & 25.04 & 49.11 & 351.1 & 14.4 & 24.29 \\
\hline & \multirow{6}{*}{$\mathrm{AE}$} & $\mathrm{C}$ & 4.00 & 3.09 & 12.15 & 0.51 & 0.30 & 6.77 & 5.07 & 22.3 & 1.1 & 19.08 \\
\hline & & $\mathrm{S}$ & 3.85 & 3.00 & 17.76 & 0.47 & 0.48 & 11.80 & 6.82 & 36.9 & 1.6 & 23.02 \\
\hline & & SN & 3.85 & 3.02 & 14.36 & 0.51 & 0.47 & 6.59 & 7.43 & 42.8 & 1.9 & 22.38 \\
\hline & & SP & 4.27 & 3.28 & 13.41 & 0.68 & 0.40 & 8.17 & 5.82 & 30.2 & 1.4 & 21.16 \\
\hline & & SNP & 3.79 & 2.92 & 17.83 & 0.62 & 0.68 & 8.79 & 7.97 & 42.1 & 2.0 & 21.34 \\
\hline & & SNPK & 3.79 & 2.90 & 17.98 & 0.44 & 0.46 & 12.03 & 4.31 & 39.2 & 2.1 & 18.83 \\
\hline
\end{tabular}

$\mathrm{C}$ - control - no fertiliser; $\mathrm{S}$ - ground serpentinite; $\mathrm{SN}$ - serpentinite + nitrogen; $\mathrm{SP}-$ ground serpentinite $+\mathrm{P} ; \mathrm{SNP}-$ ground serpentinite + NP; SNPK - ground serpentinite $+\mathrm{NP}+\mathrm{K}$.

Table 2. The average values of the properties of the test soils in 2011

\begin{tabular}{|c|c|c|c|c|c|c|c|c|c|c|c|c|}
\hline \multirow[t]{2}{*}{ Plots } & \multirow[t]{2}{*}{ Horizon } & \multirow{2}{*}{$\begin{array}{l}\text { Type of } \\
\text { fertilisa- } \\
\text { tion }\end{array}$} & \multirow[t]{2}{*}{$\mathrm{pH} \mathrm{H} \mathrm{H}_{2} \mathrm{O}$} & \multirow[t]{2}{*}{$\mathrm{pH} \mathrm{KCl}$} & $\mathrm{Y}$ & $\mathrm{Hw}_{(}\left(\mathrm{Al}^{3+}\right)$ & $\mathrm{S}$ & $\mathrm{T}_{\mathrm{e}}$ & \multirow[t]{2}{*}{$\mathrm{V}_{\mathrm{e}}(\%)$} & $\begin{array}{c}\text { Organic } \\
\mathrm{C}\end{array}$ & $\mathrm{N}$ total & \multirow[t]{2}{*}{$\mathrm{C}: \mathrm{N}$} \\
\hline & & & & & \multicolumn{4}{|c|}{$\operatorname{cmol}(+) \cdot \mathrm{kg}^{-1}$} & & \multicolumn{2}{|c|}{$\mathrm{g} \cdot \mathrm{kg}^{-1}$} & \\
\hline \multirow{12}{*}{ Wisła } & \multirow{6}{*}{ Ofh } & $\mathrm{C}$ & 3.35 & 2.60 & 138.26 & 12.16 & 2.61 & 17.91 & 14.61 & 340.9 & 15.0 & 22.77 \\
\hline & & $\mathrm{S}$ & 3.97 & 3.03 & 88.40 & 9.09 & 6.36 & 16.35 & 41.58 & 346.9 & 15.6 & 22.24 \\
\hline & & SN & 3.82 & 2.91 & 120.92 & 9.25 & 5.60 & 16.16 & 34.43 & 338.5 & 14.7 & 22.87 \\
\hline & & SP & 3.73 & 2.9 & 87.23 & 15.75 & 3.74 & 20.61 & 19.40 & 319.1 & 14.9 & 21.48 \\
\hline & & SNP & 4.05 & 3.12 & 83.64 & 5.79 & 7.75 & 15.21 & 51.26 & 358.2 & 15.5 & 23.03 \\
\hline & & SNPK & 3.79 & 2.92 & 87.11 & 9.23 & 5.53 & 16.06 & 34.53 & 342.8 & 15.4 & 22.26 \\
\hline & \multirow{6}{*}{$\mathrm{AE}$} & $\mathrm{C}$ & 3.63 & 2.84 & 16.53 & 6.39 & 0.18 & 7.59 & 2.54 & 39.7 & 2.2 & 18.16 \\
\hline & & $\mathrm{S}$ & 3.64 & 2.83 & 17.07 & 10.3 & 0.25 & 11.59 & 2.95 & 45.4 & 2.4 & 19.37 \\
\hline & & SN & 3.64 & 2.83 & 19.96 & 6.85 & 0.26 & 7.92 & 3.31 & 51.2 & 2.8 & 18.38 \\
\hline & & SP & 3.80 & 2.93 & 17.89 & 9.44 & 0.16 & 10.34 & 2.17 & 38.5 & 2.0 & 19.20 \\
\hline & & SNP & 3.63 & 2.84 & 18.29 & 6.97 & 0.23 & 7.91 & 3.25 & 43.4 & 2.2 & 19.60 \\
\hline & & SNPK & 3.72 & 2.81 & 16.71 & 9.73 & 0.18 & 10.51 & 2.26 & 26.5 & 1.6 & 17.04 \\
\hline
\end{tabular}

$\mathrm{C}$ - control - no fertiliser; $\mathrm{S}$ - ground serpentinite; $\mathrm{SN}$ - serpentinite + nitrogen; $\mathrm{SP}$ - ground serpentinite $+\mathrm{P}$; $\mathrm{SNP}-$ ground serpentinite + NP; SNPK - ground serpentinite + NP + K. 
Table 3. The average content of the macroelements of the test soils in 2010 and 2011

\begin{tabular}{|c|c|c|c|c|c|c|c|c|c|c|c|c|}
\hline \multirow{3}{*}{ Plots } & \multirow{3}{*}{ Horizon } & \multirow{3}{*}{$\begin{array}{l}\text { Type of } \\
\text { fertilisa- } \\
\text { tion }\end{array}$} & \multicolumn{5}{|c|}{2010} & \multicolumn{5}{|c|}{2011} \\
\hline & & & $\mathrm{Ca}$ & K & $\mathrm{Mg}$ & $\mathrm{Na}$ & $\mathrm{P}$ & $\mathrm{Ca}$ & K & $\mathrm{Mg}$ & $\mathrm{Na}$ & $\mathrm{P}$ \\
\hline & & & \multicolumn{5}{|c|}{$\mathrm{mg} \cdot \mathrm{kg}^{-1}$} & \multicolumn{5}{|c|}{$\mathrm{mg} \cdot \mathrm{kg}^{-1}$} \\
\hline \multirow{12}{*}{ Wisła } & \multirow{6}{*}{ Ofh } & C & 62.03 & 41.18 & 9.97 & 2.47 & 18.43 & 30.99 & 21.64 & 5.40 & 2.58 & 17.62 \\
\hline & & $\mathrm{S}$ & 70.57 & 34.59 & 79.66 & 2.12 & 16.10 & 30.35 & 20.98 & 51.62 & 2.56 & 20.11 \\
\hline & & SN & 77.63 & 35.68 & 88.95 & 2.95 & 15.87 & 27.70 & 19.94 & 43.3 & 3.37 & 17.34 \\
\hline & & SP & 87.10 & 38.67 & 67.21 & 2.44 & 35.70 & 24.25 & 17.37 & 24.21 & 2.21 & 27.72 \\
\hline & & SNP & 145.17 & 39.89 & 65.04 & 3.56 & 34.30 & 58.29 & 18.41 & 51.88 & 2.47 & 24.90 \\
\hline & & SNPK & 99.03 & 43.93 & 74.16 & 3.19 & 28.23 & 39.02 & 20.32 & 35.96 & 2.45 & 24.78 \\
\hline & \multirow{6}{*}{$\mathrm{AE}$} & $\mathrm{C}$ & 2.57 & 3.32 & 0.90 & 0.38 & 5.95 & 1.19 & 2.24 & 0.57 & 0.49 & 13.08 \\
\hline & & $\mathrm{S}$ & 3.56 & 5.04 & 1.81 & 0.62 & 4.08 & 1.42 & 2.26 & 1.33 & 0.47 & 3.58 \\
\hline & & SN & 2.77 & 3.98 & 2.45 & 0.62 & 7.00 & 1.02 & 2.14 & 1.61 & 0.45 & 7.19 \\
\hline & & SP & 2.53 & 4.00 & 1.85 & 0.35 & 10.15 & 24.25 & 17.37 & 24.21 & 2.21 & 13.30 \\
\hline & & SNP & 6.17 & 4.59 & 2.85 & 0.54 & 9.92 & 58.29 & 18.41 & 51.88 & 2.47 & 6.24 \\
\hline & & SNPK & 3.28 & 4.54 & 1.85 & 0.66 & 11.32 & 39.02 & 20.32 & 35.96 & 2.45 & 21.68 \\
\hline
\end{tabular}

Table 4. The average values of the heavy metals (as extract in solution of $1 \mathrm{M} \mathrm{HCl}$ ) in the testes soils in 2010 and 2011 (mg $\cdot \mathrm{kg}^{-1}$ of soil)

\begin{tabular}{|c|c|c|c|c|c|c|c|c|c|c|c|c|c|c|}
\hline \multirow{2}{*}{ Plots } & \multirow{2}{*}{ Horizon } & \multirow{2}{*}{$\begin{array}{l}\text { Types of } \\
\text { fertilisa- } \\
\text { tion }\end{array}$} & \multicolumn{6}{|c|}{2010} & \multicolumn{6}{|c|}{2011} \\
\hline & & & $\mathrm{Cd}$ & $\mathrm{Cr}$ & $\mathrm{Cu}$ & $\mathrm{Ni}$ & $\mathrm{Pb}$ & $\mathrm{Zn}$ & $\mathrm{Cd}$ & $\mathrm{Cr}$ & $\mathrm{Cu}$ & $\mathrm{Ni}$ & $\mathrm{Pb}$ & $\mathrm{Zn}$ \\
\hline \multirow{12}{*}{ Wisła } & \multirow{6}{*}{ Ofh } & $\mathrm{C}$ & 0.94 & 1.00 & 9.50 & 3.93 & 186.06 & 36.16 & 0.80 & 0.38 & 9.63 & 3.10 & 151.64 & 34.11 \\
\hline & & $S$ & 0.86 & 0.95 & 9.45 & 18.43 & 169.46 & 38.33 & 1.03 & 0.55 & 9.98 & 23.36 & 162.02 & 40.32 \\
\hline & & SN & 0.85 & 0.82 & 8.63 & 21.88 & 143.41 & 33.79 & 0.87 & 1.01 & 8.46 & 16.84 & 152.24 & 31.35 \\
\hline & & SP & 0.95 & 0.68 & 10.16 & 18.53 & 161.94 & 29.75 & 1.14 & 3.01 & 7.64 & 12.04 & 158.77 & 25.86 \\
\hline & & SNP & 1.06 & 0.79 & 11.40 & 19.22 & 179.96 & 35.43 & 0.66 & 0.35 & 8.11 & 23.74 & 135.49 & 30.13 \\
\hline & & SNPK & 0.81 & 0.41 & 9.00 & 17.68 & 160.08 & 31.47 & 0.91 & 0.59 & 8.42 & 15.65 & 179.43 & 28.00 \\
\hline & \multirow{6}{*}{$\mathrm{AE}$} & $\mathrm{C}$ & 0.09 & 6.15 & 1.17 & 5.48 & 20.88 & 3.03 & 0.16 & 2.15 & 1.91 & 1.84 & 32.99 & 3.61 \\
\hline & & $S$ & 0.16 & 4.50 & 1.68 & 3.63 & 24.25 & 4.81 & 0.22 & 2.69 & 2.13 & 1.65 & 33.04 & 5.35 \\
\hline & & $\mathrm{SN}$ & 0.17 & 8.08 & 1.28 & 6.56 & 22.25 & 4.27 & 0.23 & 2.10 & 1.53 & 1.01 & 40.12 & 5.07 \\
\hline & & SP & 0.12 & 19.75 & 1.90 & 15.88 & 22.96 & 3.29 & 0.14 & 2.44 & 1.27 & 1.90 & 30.21 & 3.32 \\
\hline & & SNP & 0.14 & 1.29 & 1.85 & 1.58 & 34.85 & 5.41 & 0.15 & 1.46 & 1.67 & 1.44 & 32.15 & 4.53 \\
\hline & & SNPK & 0.16 & 3.82 & 1.66 & 3.83 & 33.60 & 4.49 & 0.09 & 0.88 & 1.22 & 0.86 & 27.74 & 2.58 \\
\hline
\end{tabular}

increase in the concentration of aluminum was noted in 2010 in the AE horizon of SP and SNP fertilisation variants. The concentration of aluminum in the Ofh horizon no increase was noted. In 2011, in the increase in the aluminum concentration in Ofh horizon in the SP fertilisation variant was noted while in the AE horizon it was noted in all the fertilisation variants.
As a result the fertilisation variants used in the experiment in the soil were enriched in magnesium (tab. 3). Among the used variants of fertilisation in the $\mathrm{SN}$ variant the loss in exchangeable potassium from the soil was noted. Two years after fertilisation in the Ofh horizon phosphorus content was increased in the fertiliser variants with P in relation to the control. In 2011 


\section{DE GRUYTER OPEN}
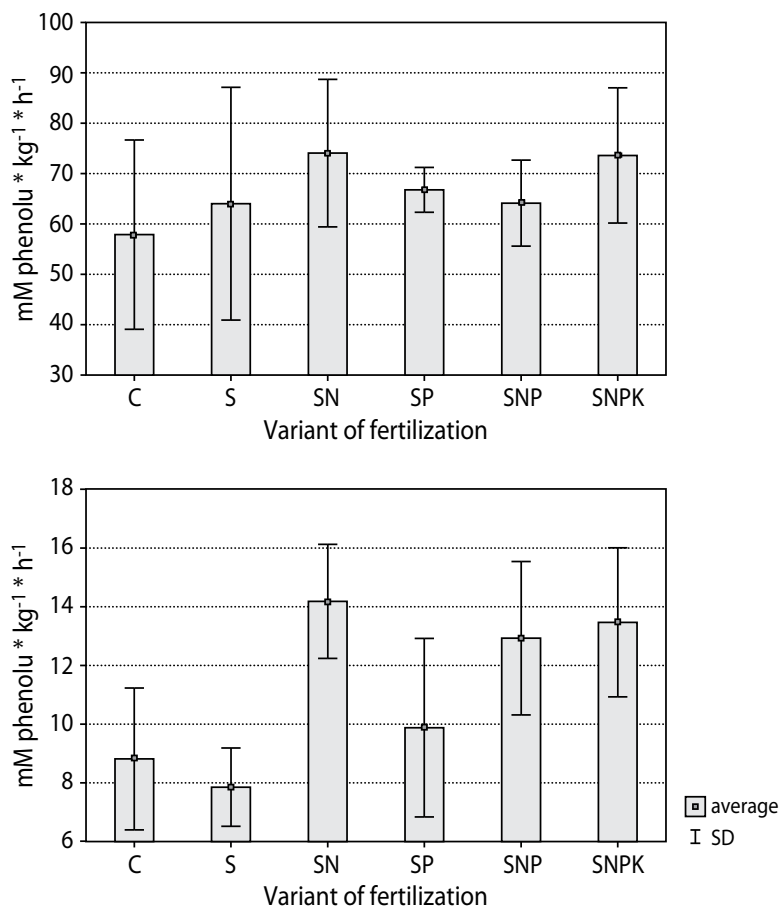

Figure 1. Phosphatase activity in Ofh and AE horizon of the Wisła plot two years after fertilisation
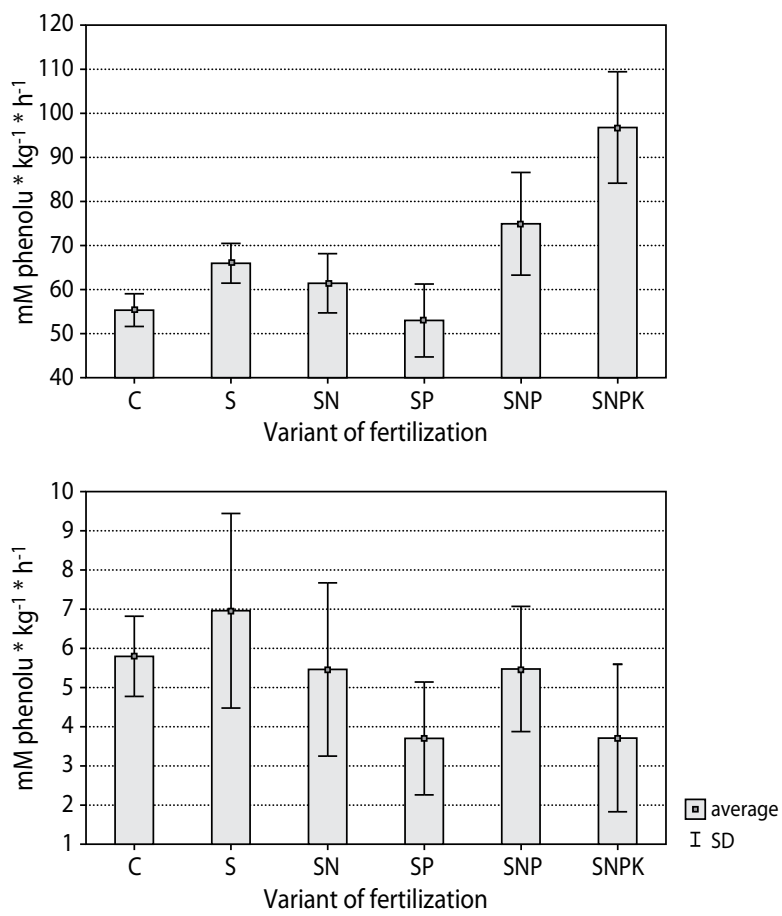

Figure 2. Phosphatase activity in Ofh and AE horizon of the Wisła plot three years after fertilisation compared to 2010 phosphorus content was decreased in the SP, SNP and SNPK variants of fertilisation (tab. 3). The substantial portion of nickel released during the weathering of serpentinite delivered from this soil, is absorbed in the surface horizon and small amounts of are released it into the soil profile (tab. 4).

The phosphatase activity in the Ofh horizon in 2011 compared with that in 2010 increased in the SNPK, SNP and $\mathrm{S}$ variants of fertilisation (fig. 1 and 2). The decrease of phosphatase activity in the control and SP and SN variants of fertilisation was observed. The phosphatase activity in the AE horizon in 2011 compared with that in 2010 decreased in the control and SNPK, SP, SN, SNP and $\mathrm{S}$ variants of fertilisation (fig. 1 and 2).

Table 5. The result of Kruskal-Wallis test of phosphatase activity

\begin{tabular}{|c|c|c|c|c|}
\hline \multirow{2}{*}{$\begin{array}{l}\text { Plot and } \\
\text { horizon }\end{array}$} & \multirow{2}{*}{$\begin{array}{c}\text { Variant } \\
\text { fertilisation }\end{array}$} & \multirow{2}{*}{$\begin{array}{l}\text { Time after } \\
\text { fertilisation }\end{array}$} & \multicolumn{2}{|c|}{$\begin{array}{c}\text { Kruskal-Wallis test } \\
\text { value }\end{array}$} \\
\hline & & & $\mathrm{H}$ & $\mathrm{P}$ \\
\hline \multirow{5}{*}{$\begin{array}{l}\text { Wisła } \\
\text { Ofh } \\
\text { horizon }\end{array}$} & $\begin{array}{l}\text { C, S, SN, SP, } \\
\text { SNP, SNPK }\end{array}$ & $\begin{array}{c}\text { Two year } \\
\text { after } \\
\text { fertilisation }\end{array}$ & 7.1161 & 0.0000 \\
\hline & SNPK-C & \multirow{4}{*}{$\begin{array}{c}\text { Three } \\
\text { years after } \\
\text { fertilisation }\end{array}$} & \multirow{4}{*}{29.7497} & 0.0003 \\
\hline & SNPK-SN & & & 0.0155 \\
\hline & SNP-SP & & & 0.0497 \\
\hline & SNPK-SP & & & 0.0001 \\
\hline \multirow{5}{*}{$\begin{array}{c}\text { Wisła } \\
\text { AE } \\
\text { horizon }\end{array}$} & SN-C & \multirow{4}{*}{$\begin{array}{c}\text { Two year } \\
\text { after } \\
\text { fertilisation }\end{array}$} & \multirow{4}{*}{29.9993} & 0.0072 \\
\hline & SN-S & & & 0.0004 \\
\hline & SNP-S & & & 0.0143 \\
\hline & SNPK-S & & & 0.0042 \\
\hline & SP-S & $\begin{array}{c}\text { Three } \\
\text { years after } \\
\text { fertilisation }\end{array}$ & 15.5203 & 0.0275 \\
\hline
\end{tabular}

In 2010, no statistically significant differences were found between the variants of fertilisation, that is, the activity of phosphatases in the Ofh horizon (tab. 5). In 2011, there were statistically significant differences between the variants SNPK and C, SNPK and SN, SNP and SNPK, SP and SP in the enzymatic activities of phosphatases in the Ofh horizon were noted. In 2010, no statistically significant differences were noted between SN and C variants, SN and S, S and SNP, and SNPK and $\mathrm{S}$ in the activities of phosphatases in the AE horizon. In 2011, no statistically significant differences be- 
Table 6. Correlation between phsphatase activity $\left(\mathrm{mM}\right.$ phenolu $\left.\cdot \mathrm{kg}^{-1} \cdot \mathrm{h}^{-1}\right)$ and soil properties $(\mathrm{n}=18)$

\begin{tabular}{|c|c|c|c|c|c|c|c|c|c|c|c|}
\hline \multirow{2}{*}{$\begin{array}{l}\text { Time after } \\
\text { fertlization }\end{array}$} & \multirow{2}{*}{ Horizon } & \multirow{2}{*}{$\begin{array}{l}\mathrm{pH} \text { in } \\
\mathrm{H}_{2} \mathrm{O}\end{array}$} & \multirow{2}{*}{$\begin{array}{c}\mathrm{pH} \text { in } \\
\mathrm{KCl}\end{array}$} & Corg & Ntotal & \multirow{2}{*}{$\mathrm{C} / \mathrm{N}$} & $\mathrm{Ca}$ & $\mathrm{K}$ & $\mathrm{Mg}$ & $\mathrm{Na}$ & $\mathrm{P}$ \\
\hline & & & & & & & \multicolumn{5}{|c|}{$\mathrm{mg} \cdot \mathrm{kg}^{-1}$} \\
\hline \multirow{2}{*}{$\begin{array}{l}\text { Two years after } \\
\text { fertilisation }\end{array}$} & Ofh horizon & -0.02 & 0.04 & 0.56 & 0.48 & 0.37 & 0.13 & 0.55 & 0.37 & 0.15 & 0.19 \\
\hline & AE horizon & -0.25 & -0.07 & 0.41 & 0.45 & -0.06 & 0.20 & 0.14 & 0.40 & 0.22 & 0.64 \\
\hline \multirow{2}{*}{$\begin{array}{l}\text { Three years after } \\
\text { fertilisation }\end{array}$} & Ofh horizon & 0.34 & 0.36 & 0.10 & 0.10 & 0.08 & 0.41 & 0.15 & 0.37 & 0.17 & 0,21 \\
\hline & AE horizon & -0.63 & -0.32 & 0.65 & 0.65 & 0.04 & 0.30 & 0.66 & 0.54 & 0.45 & 0.59 \\
\hline
\end{tabular}

Significantly correlation are highlighted.

tween the SP and S variant were found in the enzymatic activity of phosphatases in the AE horizon.

The higher correlation between enzymatic activity and physico-chemical properties of soils observed two and three years after the fertilisation. After 2 years of fertilisation phosphatase activity in the Ofh horizon correlated with the content of $\mathrm{C}$ and $\mathrm{N}$ and $\mathrm{K}$ fertilisation. Three years after fertilisation the phosphatase activity in the AE horizon correlated with the $\mathrm{pH}$ of the $\mathrm{H}_{2} \mathrm{O}$ content of $\mathrm{C}, \mathrm{N}, \mathrm{K}$ and $\mathrm{Mg}$ (tab. 6).

\section{Discussion}

They used fertilisation with serpentinite in combination with nitrogen, phosphorus and potassium fertilisers that affected the activity of phosphatase. Many authors have studied the impact of mineral fertilisers on the activity of phosphatases. Johnson et al. (2005) studied the effect of liming and $\mathrm{N}$ fertilisation on the phosphatase activities. Application of inorganic P can repress the synthesis of phosphomonoesterases in soil because it inhibits the expression of PHO genes and, indeed, phosphate inhibits the phosphatase activities of soil (Juma and Tabatabai 1977). However, the absence of a response of phosphatase activities to $\mathrm{P}$ addition has also been reported. For example, the application of triple superphosphate to an oak soil in 1992 did not affect acid phosphomonoesterase activity of soil samples taken in 1993 and 1994 (Schneider et al. 2001). Addition of phosphate with glucose and inorganic $\mathrm{N}$ did not stimulate the phosphomonoesterase activity ( $\mathrm{pH}$ 6.5) of soil, whereas the stimulation occurred in the respective soil treated only with glucose and inorganic N (Nannipieri et al. 1978). Presumably, the enzyme activity was not decreased by phosphate due to the presence of extracellular phosphomonoesterases stabilised by soil colloids or due to the presence of constitutive microbial phosphomonoesterase in soil. Enzyme assays discriminating the activities of extracellular stabilised enzymes from activities of enzymes associated with soil microorganisms would permit an understanding of the underlying mechanisms (Nannipieri et al. 2011). In the forest soil, after 6 years of total fire reported higher content of available phosphorus and lower phosphatase activity compared to control soil of pine stands growing in the neighborhood of the fire (Januszek et al. 2001).

Badalucco et al. (1992) studied the effects of liming on the biochemical properties of acid soils under spruce. They noted a clear increase in dehydrogenase activity but not in phosphatase. In this study, in the Ofh horizon three years after fertilisation the decrease of phosphatase activity in SP variants of fertilisation were observed. In the AE horizon, decrease in phosphatases activity in SN, SP, SNP and SNPK of fertilisation were observed. The phosphatase activity in the $\mathrm{O}$ horizon both 2 and 3 years after fertilisation was always higher in the variants where $\mathrm{N}$ was used as compared to control plots. This regularity was also noted by Zglimbea et al. (1996) where in the conducted studies an increase in acid phosphatase after the fertilisation of $\mathrm{N}$ was noted. However, in the AE horizon after phosphorus fertilisation the activity of phosphatases decreased. Wang et al. (2008) in their study confirm the hypothesis that phosphorus inhibited the activity of this enzyme. When $\mathrm{N}$ and $\mathrm{P}$ were used in the fertilisation at the same time the activity of phosphatases increased. The best results were achieved at a dose of $100-150 \mathrm{~kg} \mathrm{~N} / \mathrm{ha}$ and $40 \mathrm{~kg} \mathrm{P} / \mathrm{ha}$. This is explained by the synergistic effect of the two elements in fertilisation. The same results were also obtained by Kummerova and Buresova (1990). Horizons of humus 


\section{DE GRUYTER OPEN

showed the highest activity of enzymes. The activity decreased with depth of soil profile. The high activity of enzymes in the upper horizons of the soil is associated with the presence of microorganisms and their activity and the content of organic matter constituting the feeding base. This phenomenon is connected mainly with the profiled location of humus in the soil and the amount of available carbon substrates for the microorganisms and enzymes decreases with the depth of the soil. The obtained results of fall in activity in the soil profile is fully consistent with the observations of Wang and Qin (2006). Phosphatase activity in each case in the AE horizon was less than 3 years after fertilisation than two years after fertilisation, which can be explained by a greater accumulation of fertilisers used in the upper horizons of the soil.

The activity of phosphatase as measured in the control plots was lower in 2011 than in 2010 in O and AE horizon. Additional factors that determined the activity of the enzymes were the climatic conditions in the areas of research, particularly temperature and precipitation. The years 2010 and 2011 during which the study was conducted differed in the mean annual temperature $\left(6.4^{\circ} \mathrm{C}\right.$ and $\left.7.2^{\circ} \mathrm{C}\right)$ and rainfall $(1347 \mathrm{~mm}$ and $1114 \mathrm{~mm})$. According to the previously noted observations of authors, temperature and moisture are factors determining the enzymatic activity. Huang et al. (2011) showed negative effects of precipitation on forest soil acid phosphatase activity. The results show that a reasonable distribution of water plays a critical role in controlling the rate of $\mathrm{P}$ cycling.

Many studies have shown that soil contamination with heavy metals may have a negative impact on the biochemical activity of soil (Kucharski et al. 2009). Kandeler et al. (1996) observed a reduction of the enzymatic activity due to the increased concentration of heavy metals in soil. High heavy metal contamination reduces the amount of soil microorganisms and influences nutrient circulation. No decrease in phosphatase activity after fertilisation of serpentinite in 2010 was recorded. Nickel delivered to the soil did not inhibit phosphatase activity of the soils. Phosphatase activity in the $\mathrm{O}$ horizon 2 years after the fertilisation has increased. This may prove that the increase in the microbial activity after the fertilisation of all variants and the absence of negative effects of the applied Ni.

\section{Conclusions}

1. Fertilisation of serpentinite stimulates the activity of phosphatase in soil under spruce stands. The positive impact is reflected in the organic horizon. Less activity was noted in the AE horizon in all the fertiliser combinations three years after the fertilisation.

2. The result shows that temperature and moisture play a considerable role in creating phosphatase activity.

3. Heavy metals especially nickel do not have a negative impact on the phosphatase activity. Soils of spruce stands show the absence of toxic concentrations of heavy metals.

4. Fertilisation of serpentinite improves the chemical properties $-\mathrm{pH}$ was increased, reduction of molar ratio of exchangeable calcium to magnesium form was noted.

\section{Acknowledgement}

This work was financed by the State Forests National Forest Holding in Poland within the project: 3/08-Forest management measures improving the growth, nutrition and health conditions in forest regeneration areas and endangered stands in the Beskidy Mts, with particular emphasis on soil revitalisation with dolomites and new multicomponent long-acting fertilisers.

\section{References}

Attwill P.M., Adams M.A. 1993. Nutrient cycling in forests. New Phytologist, 124, 561-582.

Badalucco L., Grego S., Dell'Orco S., Nannipieri P. 1992. Effect of liming on some chemical, biochemical, and microbiological properties of acid soils under spruce (Picea abies L.). Biology and Fertility of Soils, 14(2), 76-83.

Bielińska E.J. 2005. Ocena stanu środowiska glebowego ogrodów działkowych z terenów o różnym oddziaływaniu antropopresji poprzez badanie aktywności fosfataz. Zeszyty Problemowe Postępów Nauk Rolniczych, 505, 51-58. 
Ekenler M., Tabatabai M.A. 2003. Effects of liming and tillage systems on microbial biomass and glycosidases in soils. Biology and Fertility of Soils, 39, 51-61.

Haziev F.H. 1976. Fermentativnaâ aktivnost počv. Izd. Nauka, Moskwa.

Huang W., Liu J., Zhou G., Zhang D., Deng Q. 2011. Effects of precipitation on soil acid phosphatase activity in three successional forests in southern China. Biogeosciences, 8, 1901-1910.

Januszek K., Lasota J., Gruba P., Domicz G. 2001. Właściwości fizyczno-chemiczne i biochemiczne gleb bielicowych 6 lat po pożarze całkowitym lasu. Acta Agraria et Silvestria Series Silvestris, 39, 45-61.

Johnson D., Leake J.R., Read D.J. 2005. Liming and nitrogen fertilization affects phosphatase activities, microbial biomass and mycorrhizal colonistaion in upland grassland. Plant and Soil, 271, 157-164.

Juma N.G., Tabatabai M.A. 1977. Effects of trace elements on phosphase activity in soils. Soil Science Society of America Journal, 41,343-346.

Kandeler E., Kampichler C., Horak O. 1996. Influence of heavy metals on the functional diversity of soil communities. Biology and Fertility of Soils, 23, 299-306.

Kramer M., Yerdei G. 1959. Application of the method of phosphatase activity determination in agricultural chemistry. Soviet Soil Science, 9, 1100-1103.

Kucharski J., Boros E., Wyszkowska J. 2009. Biochemical activity of nickel-contaminated soil. Polish Journal of Environmental Studies, 18(6), 1039-1044.

Kummerova M., Buresova I. 1990. The effect exogenous phosphate deficiency on the activity of acid phosphatase of the root of two maize genotypes. Plant Physiology and Biochemistry, 32 (1). 1-17.
Mijangos I., Pérez R., Albizu I., Garbisu C. 2006. Effects of fertilization and tillage on soil biological paramters. Enzyme and Microbial Technology, 40,100-106.

Nannipieri P., Johanson R.L., Paul E.A. 1978. Criteria for measurement of microbial growth and activity in soil. Soil Biology and Biochemistry, 10, 223-229.

Nannipieri P., Grego S., Ceccanti B. 1990. Ecological significance of the biological activity in soil. Soil Biochemistry, 6, 293-355.

Nannipieri P., Giagnoni L., Landi L., Renella G. 2011. Role of phosphatase enzymes in soil. Soil Biology, 26, 215-243. DOI 10.1007/978-3-642-15271-9_9

Schneider K., Turrion M.B., Grierson P.F., Gallardo J.F. 2001. Phosphatase activity, microbial phosphorus, and fine root growth in forest soils in the Sierra de Gata, western Spain. Biology and Fertility of Soils, 34,151-155.

Tabatabai M.A., Bremner J.M. 1969. Use of $p$-nitrophenol phosphate for assay of soil phosphatase activity. Soil Biology and Biochemistry, 1, 301-307.

Wang X.C., Lu Qin. 2006. Beta-glucosidase activity in paddy soils of the Taihu Lake region, China. Pedosphere, 16 (1), 118-124.

Wang Q.K., Wang S.L., Liu X.Y. 2008. Responses to $\mathrm{N}$ and $\mathrm{P}$ fertilization in a young Eucalyptus dunnii plantation: Microbial properties, enzyme activities and dissolved organic matter. Applied Soil Ecology, 40, 484-490.

Wang J.B., Chen Z.H., Chen L.J., Zhu A.N., Wu Z.J. 2011. Surface soil phosphorus and phosphatase activities affected by tillage and crop residue input amounts. Plant, Soil and Evironment, 57, 251-257.

Zglimbea G.R., Mihaila V. 1996. Influence of nitrogen and phosphorus rates on acid phosphatase activity. Romanian Agricultural Research, 5/6, 59-69. 